\title{
Life History and Description of Immature Stages of Euaresta stigmatica (Diptera: Tephritidae) on Ambrosia spp. (Asteraceae) in Southern California
}

\author{
DAVID H. HEADRICK, RICHARD D. GOEDEN, AND JEFFREY A. TEERINK
}

Department of Entomology, University of California, Riverside, CA 92521

\begin{abstract}
Ann. Entomol. Soc. Am. 88(1): 58-71 (1995)
ABSTRACT Euaresta stigmatica Coquillett is bivoltine and nearly monophagous on four native ragweeds, Ambrosia spp. (Asteraceae), in the southwestern United States. In southern California, larvae of the spring $\left(F_{1}\right)$ generation develop singly in and feed on one or both ovules of young fruiting involucres of Ambrosia ilicifolia (Gray) Payne, with a small proportion infesting the staminate involucres. Adults emerge after $\approx 1 \mathrm{mo}$, with their reproductive organs immature. The $\mathrm{F}_{2}$ generation develops in the involucres of fall-blooming Ambrosia acanthicarpa Hooker. The egg is described and illustrated for the first time for any species of Euaresta. First, second, and third instars and the puparium are described and illustrated for the first time for $E$. stigmatica. The posterior spiracular plates of all three instars bear only three interspiracular processes, whereas the larvae and puparia of all other nonfrugivorous tephritids described to date bear four such processes. Adult behaviors described from field and laboratory studies include courtship, copulation, and territoriality. Male courtship displays include three behaviors previously undescribed for Tephritidae: a side-to-side dance, rapid side stepping, and a middle leg abduction. Hymenopterous parasitoids of E. stigmatica include two solitary, primary larval-pupal, endoparasitoids, Eurytoma sp. (Eurytomidae) and Pteromalus sp. (Pteromalidae). Potential use of E. stigmatica as a biological control agent for ragweeds in Eurasia is discussed.
\end{abstract}

KEY WORDS Euaresta, biology, behavior

THE CURRENT STUDY OF Euaresta stigmatica Coquillett was an outgrowth of faunistic studies of the insect associates of ragweeds (Ambrosia spp.) and other Ambrosiinae (Asteraceae) in southern California conducted by Goeden \& Ricker (1974a, b; 1975; 1976a-c; 1986), Hilgendorf \& Goeden (1983), and Goeden \& Teerink (1993). The genus Euaresta is native and widespread in North and South America (Norrbom 1993). Six of the eight Nearctic species occur in California (Foote et al. 1993), where E. stigmatica is common and widespread.

Little is known of the biologies of most Euaresta spp. Marlatt (1891) briefly described the biology of Euaresta aequalis (Loew) and Phillips (1946) described its larvae and their feeding behavior. Both E. aequalis and Euaresta bullans (Wiedemann) have been introduced into Australia for biological control of Xanthium spp. (Julien 1992). Foote (1984) summarized the host-plant associations for North American species of Euaresta that specialize on Ambrosia and Xanthium spp. Batra (1979) studied the biology and behavior of $E$. bella (Loew) and Euaresta festiva (Loew) in assessing them as potential agents for the biological control of ragweeds accidentally introduced to Eurasia from North America (Goeden \& Teerink 1993). We provide new knowledge of the biology, immature stages, and reproductive behavior of $E$. stigmatica derived from field and laboratory studies on fall- and spring-blooming, native ragweeds in southern California.

\section{Materials and Methods}

Preliminary field studies and collections of $E$. stigmatica were made in 1969-1973 on Ambrosia ilicifolia (Gray) Payne and Ambrosia acanthicarpa Hooker at many locations throughout southern California (Goeden \& Ricker 1974a, 1976b). More intensive field studies were conducted in 1991 and 1992 at the Edmund C. Jaeger Nature Preserve, Desert Center, Riverside County, on A. ilicifolia, its spring-blooming host, and on or near the campus of the University of California, Riverside, on A. acanthicarpa, its fall-blooming host. Bulk samples of infested ragweed inflorescences were collected at these sites and brought to the laboratory in ice chests in an air-conditioned van and stored under refrigeration for subsequent dissection, measurement, photography, and description of all life stages.

Immature stages were described using scanning electron microscopy of two ova dissected from gravid, field-collected females, as well as four, sev- 


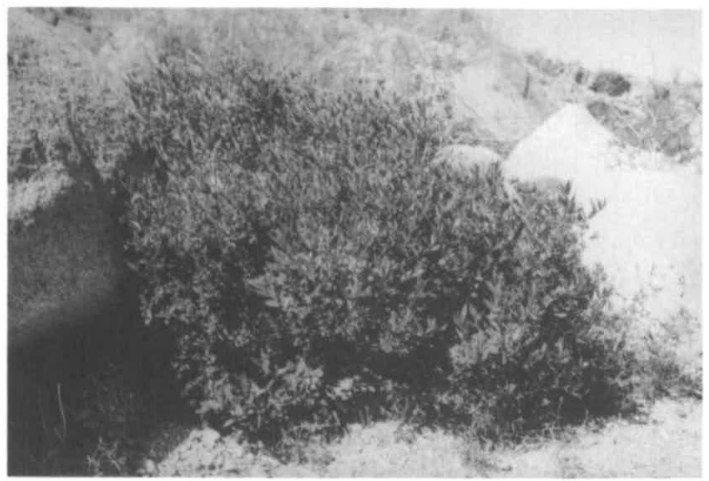

Fig. 1. A. ilicifolia study plant at the E. Jaeger Preserve.

en, and nine each first, second, and third instars and four puparia dissected from fruiting involucres. All specimens for microscopy were fixed in $70 \% \mathrm{EtOH}$, dehydrated to absolute $\mathrm{EtOH}$, sonicated for $\approx 1 \mathrm{~min}$ in Hexanes (Fisher, Fair Lawn, $\mathrm{NJ}$ ) to remove accumulated debris, rehydrated to distilled water, post fixed in $2 \%$ aqueous osmium tetroxide for $24 \mathrm{~h}$, then dehydrated to absolute EtOH, critical-point dried, mounted on stubs, sputter coated with a gold-palladium alloy and examined on a JEOL JSM C35 scanning electron microscope in the Department of Nematology, University of California, Riverside. Micrographs were prepared on Polaroid P/N 55 film at $15 \mathrm{kV}$ accelerating voltage.

Adults were reared from puparia dissected from fruiting involucres held in individual, glass-shell vials in humidity chambers at $22-24^{\circ} \mathrm{C}$ and $76 \% \mathrm{RH}$. Newly emerged adults were isolated in clear plastic cages $(850 \mathrm{ml})$ fitted with screened lids for ventilation, basal water reservoirs, and provisioned with honey and protein hydrolyzate (Headrick \& Goeden 1993). Five mating trials lasting 2 wk each were conducted with virgin adults held in disposable, plastic petri dish arenas (10-cm diameter) (Headrick \& Goeden 1993). Mating trials were conducted in the laboratory under artificial lighting between 0900 and 1800 hours PST.

Field observations of reproductive behaviors were made for at least $4 \mathrm{~h}$ each day on 25 February and 4, 11, 18, and 24 March 1992, at the Jaeger Reserve, where A. ilicifolia plants were located in a deep, N/S-oriented, dry, sandy wash at an elevation of $850 \mathrm{~m}$. A single plant $(\approx 1$ by $2 \mathrm{~m}$ wide and $1 \mathrm{~m}$ tall) located between large granite boulders was the primary study location (Fig. 1). This plant's stems (0.3-0.6 m long) had shorter branches, spiny holly-like leaves, and apical spikes of staminate involucres above the separate, pistillate, fruiting involucres. This study area and this same plant had been noted by R.D.G. 20 yr earlier during a study of the insect fauna of this native ragweed to host "an abundance of $E$. stigmatica adults" (Goeden \& Ricker 1976a; R.D.G., unpublished data).

Euaresta names used in this article follow Foote et al. (1993) and Norrbom (1993); nomenclature on larval taxonomy follows Headrick \& Goeden (1991); nomenclature for wing displays by adults follows Headrick \& Goeden (1991), Green et al. (1993), and Goeden et al. (1994b); ragweed inflorescence morphology follows Payne (1963); and plant names follow Munz (1968, 1974). Voucher specimens of reared adults of E. stigmatica and its parasitoids reside in the research collections of R.D.G.; preserved specimens of E. stigmatica larvae and puparia are stored in separate collections maintained by J.A.T. and D.H.H. Means \pm SEM are provided throughout this article.

\section{Results and Discussion}

Taxonomy. Euaresta has 14 recognized species (Norrbom 1993), 6 of which occur in California (Foote et al. 1993). The species occurring in America north of Mexico have recently been treated by Foote et al. (1993), and those occurring in Central and South America by Norrbom (1993); both treatments included keys to adult stages. Descriptions of the immature stages of E. stigmatica are provided below for the first time.

Egg. Twenty-five ova, dissected from field-collected females, were white, superficially smooth, elongate-ellipsoidal, $0.17 \pm 0.004 \mathrm{~mm}$ wide (range, $0.14-0.20$ ) and $0.67 \pm 0.01$ long (range, $0.54-0.76$ ), with a rounded, anterior pedicel 0.02 $\mathrm{mm}$ long (Fig. $2 \mathrm{~A}$ and B), and a sharply tapered posterior end measuring $0.09 \pm 0.003 \mathrm{~mm}$ long (range, 0.06-0.12). Examination with light microscopy showed the posterior end to be free of embryonic tissues. Sixteen eggs dissected from plant tissue averaged $0.17 \pm 0.007 \mathrm{~mm}$ in width (range, $0.14-0.30$ ) and $0.64 \pm 0.008 \mathrm{~mm}$ in length (range, $0.58-0.71$ ).

This is the first description of the egg of any species of Euaresta. The general size and shape of E. stigmatica eggs are similar to those of Paroxyna genalis (Thomson) (Goeden et al. 1994b). However, the eggs of E. stigmatica are more parallel sided than described for other nonfrugivorous tephritid species (cf. Goeden \& Headrick 1991a, b; Headrick \& Goeden 1993; Goeden et al. 1994b). The elongate posterior end of $E$. stigmatica eggs also differs from other nonfrugivorous tephritid eggs described thus far, and its function remains unknown.

Third Instar. Third instar superficially smooth, barrel-shaped, slightly tapered anteriorly, rounded posteriorly (Fig. 3A); integument white with the caudal segment black; thoracic segments with minute acanthae dorsally, abdominal intersegmental area circumscribed by minute acanthae; gnathocephalon conical, laterally flattened, smooth with few rugose pads dorsally, broad serrated rugose pads laterally along mouth lumen (Fig. 3B, 1 and 

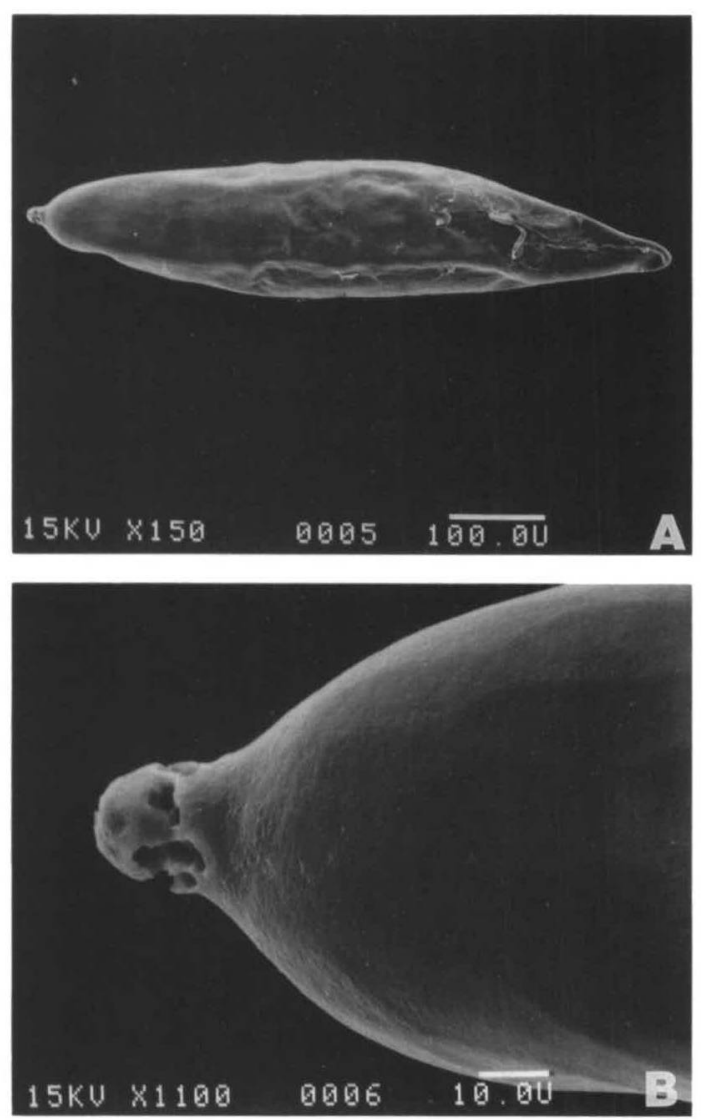

Fig. 2. Egg of E. stigmatica: (A) habitus, anterior end at left; (B) detail of pedicel, showing aeropyles.

D, 1); paired dorsal sensory organs lie mediad of anterior sensory lobes, each consisting of single dome-shaped papilla (Fig. 3B, 2 and C, 1); anterior sensory lobes bearing terminal sensory organ (Fig. 3C, 2), pit sensory organ (Fig. 3C, 3), lateral sensory organ (Fig. 3C, 4) supralateral sensory organ (Fig. 3C, 5); stomal sense organs lie ventrad of anterior sensory lobes, near mouth lumen (Fig. 3B, 3 and $\mathrm{C}, 6$ ); mouth hooks bidentate, teeth stout, bluntly conical (Fig. 3B, 4 and D, 2); median oral lobe laterally compressed, tapers apically to a fine point; attached ventrally to labial lobe (Fig. 3D, 3); labial lobe with paired sensilla (Fig. 3B, 5); lateral and ventrolateral lobes each bearing a verrucate sensillum with a central pore (Fig. 3B, 6 and 7); anterior thoracic spiracles located dorsolaterally on posterior margin of prothorax, each bearing five, rounded papillae (Fig. 3E); lateral spiracular complex on meso- and metathorax composed of small open spiracle (Fig. 3F, 1) and two, verruciform sensilla (Fig. 3F, 2); lateral spiracular complex on abdominal segments composed of an open spiracle and single verruciform sensillum; caudal segment smooth with no acanthae, bearing nonprominent, noncontiguous posterior spiracular plates (Fig. 3G, 1 ); each plate with three elongate-oval rimae $\approx 0.025 \mathrm{~mm}$ long (Fig. $3 \mathrm{H}, 1$ ), and three interspiracular processes with two to four branches each, the longest measuring $0.015 \mathrm{~mm}$ (Fig. $3 \mathrm{H}, 2$ ); stelex sensilla (Fig. 3G, 2) surrounding margin of caudal segment in four-dorsal, six-ventral arrangement; caudal segment additionally bearing a pair of verruciform sensilla ventrad of the spiracular plates (Fig. 3G, 3).

Euaresta stigmatica belongs to the tribe Tephritini, which also includes Dioxyna, Neotephritis, Paroxyna, Tephritis, Trupanea, and many other genera (Foote et al. 1993). The general larval body shape is closer to that of Trupanea and Paroxyna than to Dioxyna, Neotephritis, and Tephritis species previously examined (Novak \& Foote 1968; Goeden \& Headrick 1991b; Headrick \& Goeden 1991; Goeden et al. 1993, 1994b; unpublished data). Trupanea species can be distinguished from $E$. stigmatica by the rows of rugose pads circumscribing the prothorax (Headrick \& Goeden 1991; unpublished data). In E. stigmatica, the mouthhooks of the larvae appear to have been worn down considerably, perhaps caused by the toughness of the seed tissues. The number of sensilla in the lateral spiracular complex differ between the metathoracic and abdominal segments in $E$. stigmatica. One other species, Acuirina thoracica Curran has shown similar differences; however, the number of sensilla differed between the mesothoracic and the metathoracic and abdominal segments (Headrick \& Goeden 1993).

Phillips (1946) described the mature larva of $E$. aequalis. According to her description, E. aequalis is very similar morphologically to $E$. stigmatica with a few minor differences: the anterior thoracic spiracles in E. aequalis bear 9-10 papillae (versus 5 in stigmatica), and the caudal segment of $E$. aequalis has four interspiracular processes with two to three branches each, whereas, as noted above, $E$. stigmatica has only three processes each with two to four branches, the only tephritid species known to have only three interspiracular processes. In E. stigmatica and E. aequalis, the sensilla ventrad of the posterior spiracular plates are composed of a single verruciform papilla with a central pore. Other tephritid species have paired compound sensory organs composed of a stelex and medusoid sensillum (cf. Goeden \& Headrick 1991b; Goeden et al. 1993; 1994a, b; unpublished data).

Second Instar. Second instar elongate, cylindri$\mathrm{cal}$, tapered anteriorly, rounded posteriorly (Fig. 4A); integument creamy white; gnathocephalon conical, smooth with few rugose pads (Fig. 4B), two small, serrated pads laterad of stomal sense organs (Fig. 4B, 1); dorsal sensory organs lie dorsomedially of anterior sensory lobes, each consisting of a single, dome-shaped papilla (Fig. 4C, 1); anterior sensory lobes flattened, bearing terminal sensory organ (Fig. 4C, 2), pit sensory organ (Fig. $4 \mathrm{C}, 3$ ), lateral sensory organ (Fig. 4C, 4), supralateral sensory organ (Fig. 4C, 5); stomal sense organs 

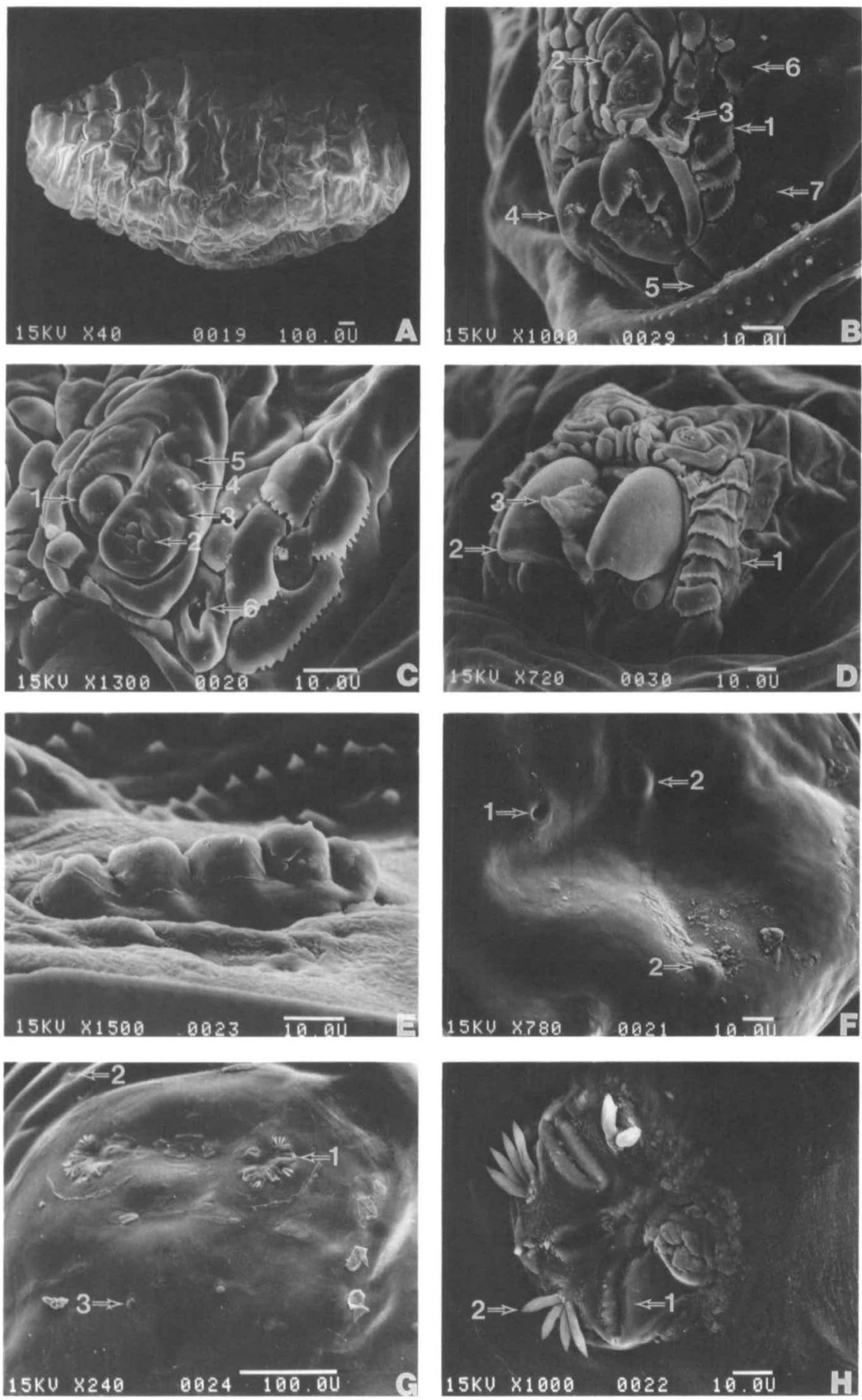

Fig. 3. Third instar of E. stigmatica: (A) habitus, anterior to left; (B) gnathocephalon, left ventrolateral view, (1) serrated rugose pads, (2) dorsal sensory organ, (3) stomal sense organ, (4) mouth hooks, (5) labial lobe sensilla, (6) lateral sensillum, (7) ventrolateral sensillum; (C) gnathocephalon, left lateral view, (1) dorsal sensory organ, (2) terminal sensory organ, (3) pit sensory organ, (4) lateral sensory organ, (5) supralateral sensory organ, (6) stomal sense organ; (D) gnathocephalon, anterior view, (1) serrated rugose pads, (2) mouth hooks, (3) median oral lobe; (E) anterior thoracic spiracles; (F) lateral spiracular complex, metathorax, (1) spiracle, (2) verruciform sensillum; (G) caudal segment, (1) posterior spiracular plate, (2) stelex sensillum, (3) verruciform sensillum; (H) caudal segment, posterior spiracular plate, (1) rimae, (2) interspiracular process. 

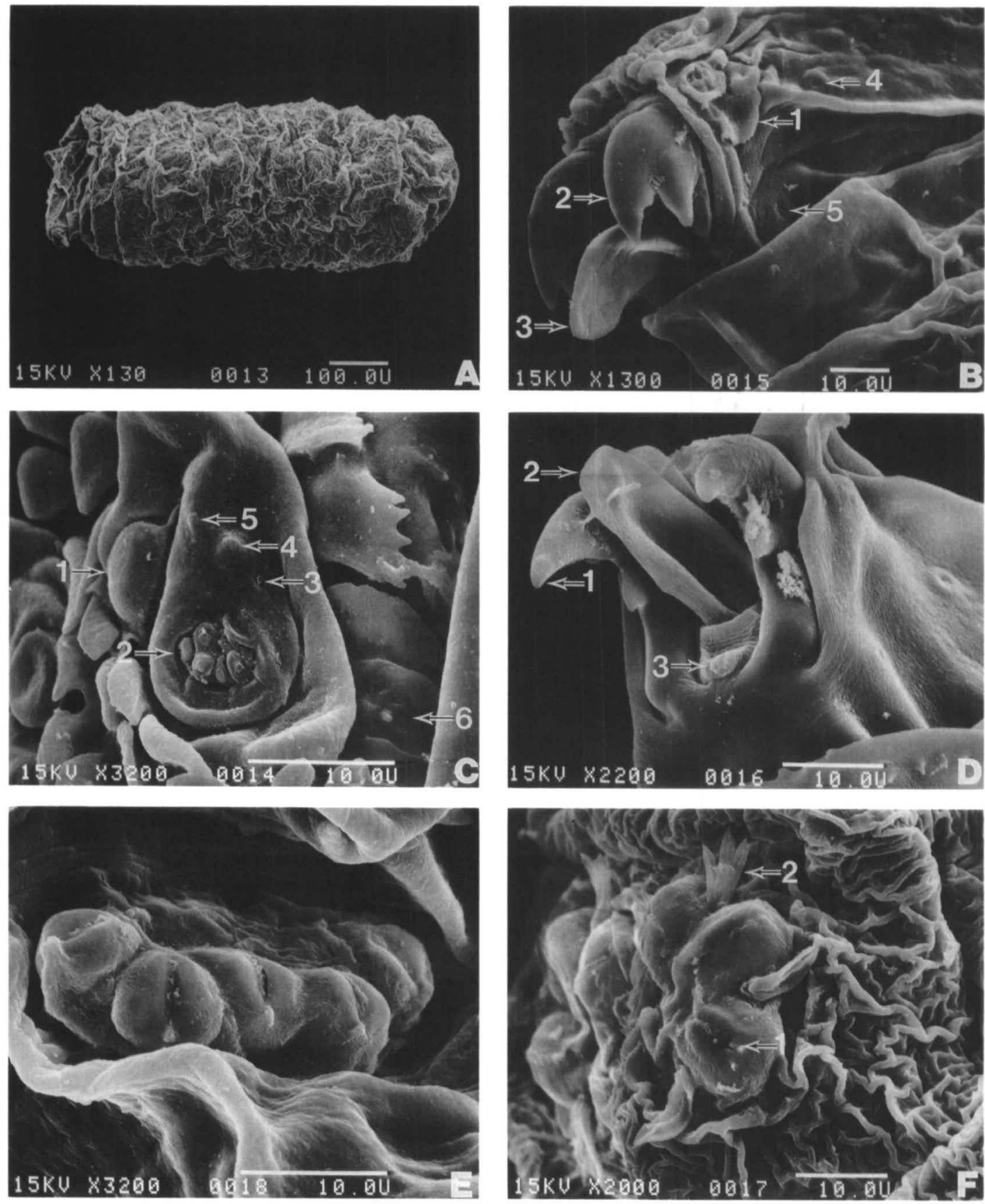

Fig. 4. Second instar of E. stigmatica: (A) habitus, anterior to left; (B) gnathocephalon, left ventrolateral view, (1) serrated rugose pads, (2) mouth hooks, (3) median oral lobe, (4) lateral sensillum, (5) ventrolateral sensillum; (C) gnathocephalon, left lateral view, (1) dorsal sensory organ, (2) terminal sensory organ, (3) pit sensory organ, (4) lateral sensory organ, (5) supralateral sensory organ, (6) stomal sense organ; (D) gnathocephalon, ventral view, (1) mouth hooks, (2) median oral lobe, (3) labial lobe sensilla; (E) anterior thoracic spiracle; (F) caudal segment, posterior spiracular plate, (1) rimae, (2) interspiracular process.

lie ventrolaterad of anterior sensory lobes (Fig. 4C, 6); mouth hooks bidentate, teeth conical, sharply pointed (Fig. 4B, 2 and D, 1); median oral lobe laterally compressed, smooth, rounded anteriorly, attached to labial lobe (Fig. 4B, 3 and D, 2); labial lobe bearing paired sensilla (Fig. 4D, 3); lateral and ventrolateral sensilla present, each bearing verruciform sensillum (Fig. 4B, 4 and 5); anterior thoracic spiracles dorsolaterad on posterior margin of prothorax, each bearing five oval papillae (Fig. 

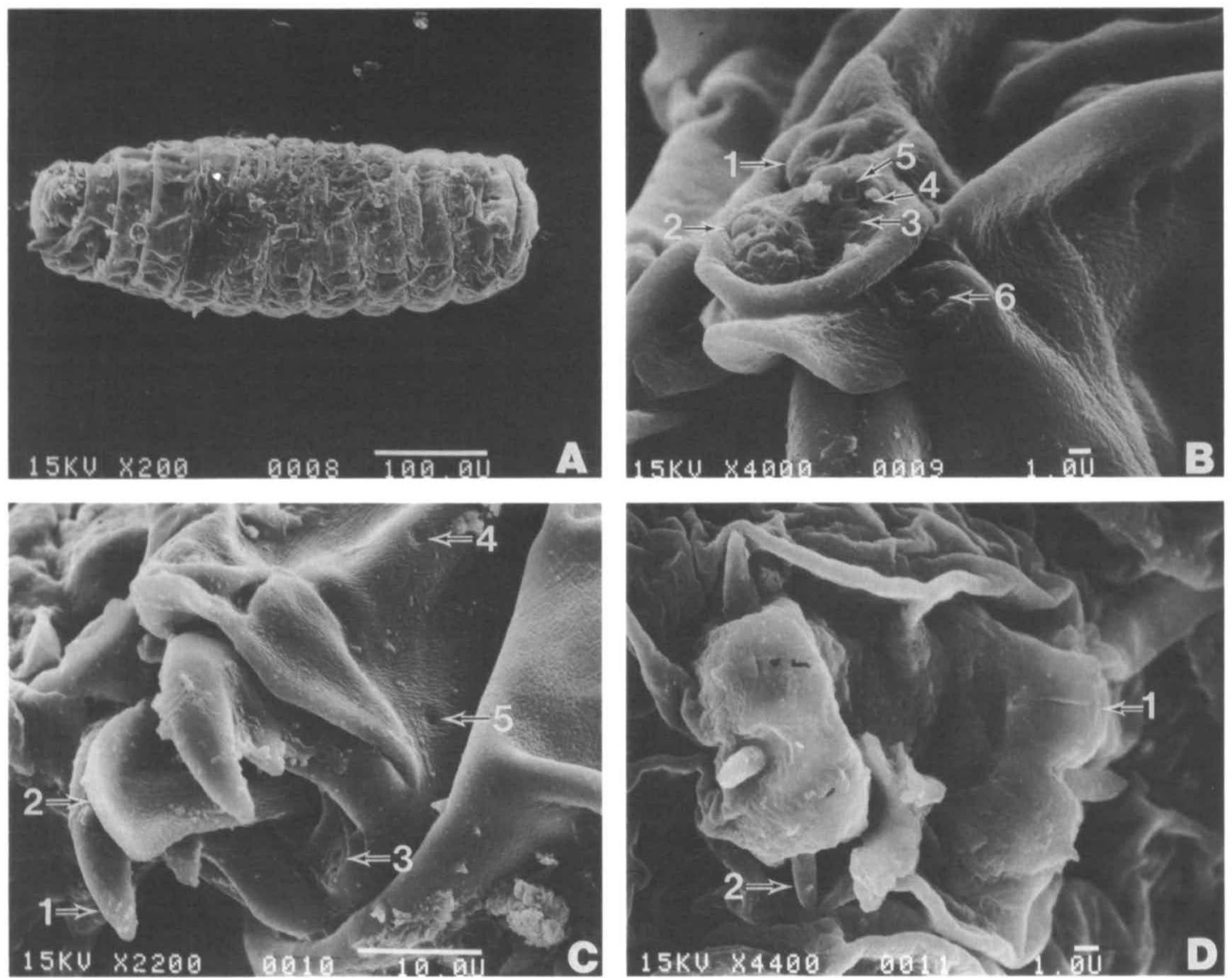

Fig. 5. First instar of E. stigmatica: (A) habitus, ventral view, anterior to left; (B) gnathocephalon, left lateral view, (1) dorsal sensory organ, (2) terminal sensory organ, (3) pit sensory organ, (4) lateral sensory organ, (5) supralateral sensory organ, (6) stomal sense organ; (C) gnathocephalon, ventrolateral view, (1) mouth hooks, (2) median oral lobe, (3) labial lobe sensilla, (4) lateral sensillum, (5) ventrolateral sensillum; (D) caudal segment, posterior spiracular plates,

(1) rimae, (2) interspiracular process.

4E); caudal segment bearing posterior spiracular plates (Fig. 4F); each plate with three oval rimae $\approx 0.015 \mathrm{~mm}$ long (Fig. $4 \mathrm{~F}, 1$ ), and three, interspiracular processes each with one to three branches, longest measuring $0.01 \mathrm{~mm}$ (Fig. 4F, 2).

The second instar differs from the third instar in its general body shape, being more cylindrical than barrel shaped. The gnathocephalon of the second instar has only two serrated rugose pads laterad of the stomal sense organ. The median oral lobe is not as distinctly tapered as in the third instar. Because of the wrinkled nature of the second instar prepared for scanning electron microscopy, the lateral spiracular complex was not observed, nor were the caudal sensilla.

First Instar. First instar cylindrical, rounded anteriorly and posteriorly, thoracic segments smooth, lacking the minute acanthae which circumscribe the abdominal segments (Fig. 5A); gnathocephalon conical, smooth with no rugose pads (Fig. 5C); dorsal sensory organs flattened, indistinct round papillae located dorsomediad of anterior sensory lobes (Fig. 5B, 1); anterior sensory lobes flattened, not well defined, bearing the terminal sensory organ (Fig. 5B, 2); pit sensory organ (Fig. 5B, 3); lateral sensory organ (Fig. 5B, 4), supralateral sensory organ (Fig. 5B, 5); stomal sense organs small, not well defined, lie ventrad of anterior sensory lobes (Fig. 5B, 6); mouth hooks bidentate, conical, sharply pointed (Fig. 5C, 1); median oral lobe laterally compressed, tapered anteriorly, attached to labial lobe (Fig. 5C, 2); labial lobe bears two sensilla (Fig. 5C, 3); lateral and ventrolateral sensilla present (Fig. 5C, 4 and 5); anterior thoracic spiracles absent; caudal segment bears the posterior spiracular plates (Fig. $5 \mathrm{D}$ ); each plate bears two oval rimae, $\approx 0.004 \mathrm{~mm}$ in length (Fig. $5 \mathrm{D}, 1$ ), and three, stout, spine-like interspiracular processes, the longest measuring $0.003 \mathrm{~mm}$ (Fig. 5D, 2); stelex sensilla located around margin of caudal segment.

First instars are more cylindrical than second instars. There are no rugose pads on the gnathocephalon of first instars, the anterior sensory lobes are 
not well defined, and the sensory organs are indistinct. The stomal sense organ is poorly defined compared with second instars. The respiratory system undergoes substantial morphogenesis between the first and second instars. First-instar E. stigmatica lack anterior thoracic spiracles; the lateral spiracles were not observed and the posterior spiracular plates bear two, small rimae.

Puparium. Puparia were either entirely dark or darkened only on both ends, elongate-ellipsoidal, truncated anteriorly, rounded posteriorly, superficially smooth, thoracic segments with minute acanthae dorsally, abdominal intersegmental areas circumscribed by minute acanthae (Fig. 6A); 16 intact puparia measured $2.84 \pm 0.07 \mathrm{~mm}$ long (range, 2.03-3.12) and $1.39 \pm 0.035 \mathrm{~mm}$ wide (range, 1.07-1.58); anterior end bearing invagination scar (Fig. 6B, 1) and raised anterior thoracic spiracles dorsolaterad of invagination scar (Fig. 6B, 2 ); caudal segment bears the posterior spiracular plates (Fig. 6C); each plate bears three oval rimae, $\approx 0.02 \mathrm{~mm}$ long (Fig. 6C, 1), and three interspiracular processes, two to five branches each, longest measuring $0.015 \mathrm{~mm}$ (Fig. 6C, 2); verruciform sensilla ventrad of spiracular plates are distinct (Fig. 6C, 3).

Distribution and Host Range. E. stigmatica is strictly Nearctic (Norrbom 1993). Its distribution north of Mexico was mapped by Foote et al. (1993). It appears to be common in the Southwest, but there are also records from Kansas and Montana. This tephritid is nearly monophagous, as known to date, reproducing solely in the involucres of four native ragweeds: A. acanthicarpa and A. ilicifolia in southern California (Goeden \& Ricker 1974a, 1976b) and A. ambrosiodes (Cavanilles) Payne, A. deltoidea (Torrey) Payne, and A. ilicifolia in southwestern Arizona (Foote 1984).

Biology. Egg. The female pierces the outer seed coat with her aculeus and inserts a single egg for approximately two-thirds of its length, pedicel last into an ovule within a fruiting involucre. In laboratory cages and field-collected samples, egg placement was either near the base or apex of a fruiting involucre (Fig. 7A). Egg pedicels typically protruded from the seed coats; however, some eggs were inserted entirely beneath the seed coat and lay hidden lengthwise, alongside an ovule. Two seeds develop within each fruiting involucre in individual chambers separated by a thin septum. In A. ilicifolia, the larva attacked both seeds in 41 of 126 (33\%) infested involucres. In contrast, in A. acanthicarpa the larva attacked only one seed in each of 57 infested involucres examined. Multiple ovipositions into individual involucres were rare; 2 larvae occurred in only 5 of $126(4 \%)$ infested involucres of A. ilicifolia and none of A. acanthicarpa.

The staminate, pollen-bearing involucres of $A$. acanthicarpa and A. ilicifolia also are occasionally infested by $E$. stigmatica. Eggs were laid singly into the staminate florets of 3 of $137(2 \%)$ staminate involucres of $A$. ilicifolia examined. Twelve males
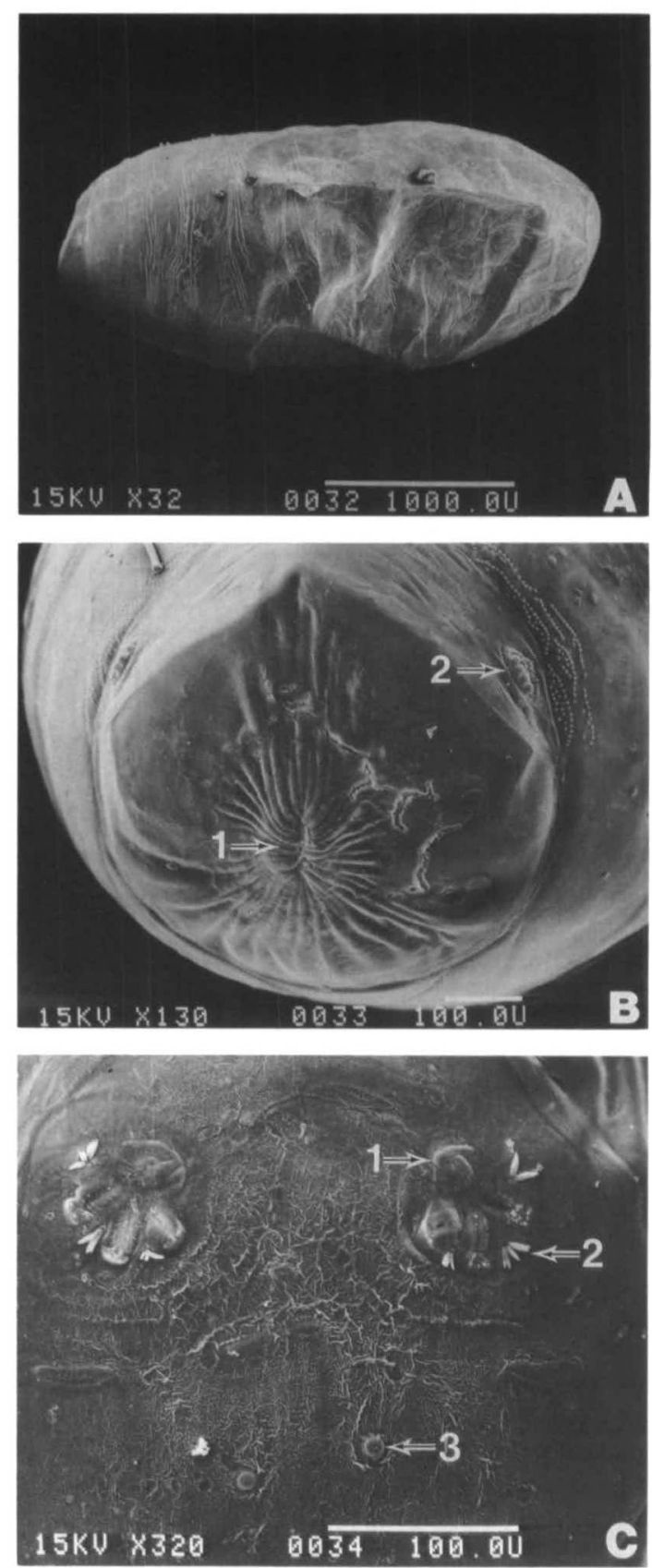

Fig. 6. Puparium of E. stigmatica: (A) habitus, anterior to left; (B) anterior end, (1) invagination scar, (2) anterior thoracic spiracle; (C) caudal segment, posterior spiracular plate, (1) rimae, (2) interspiracular process, (3) verruciform sensillum.

and four females were reared from bulk samples of isolated staminate involucres of A. acanthicarpa.

Larva. First instars eclose after $\approx 3-5 \mathrm{~d}$, exit from the posterior end of the egg after first rotating $180^{\circ}$ while still an embryo, then tunnel into and initially feed at the base of the ovule. Two involucres were dissected in which the attacked ovules 

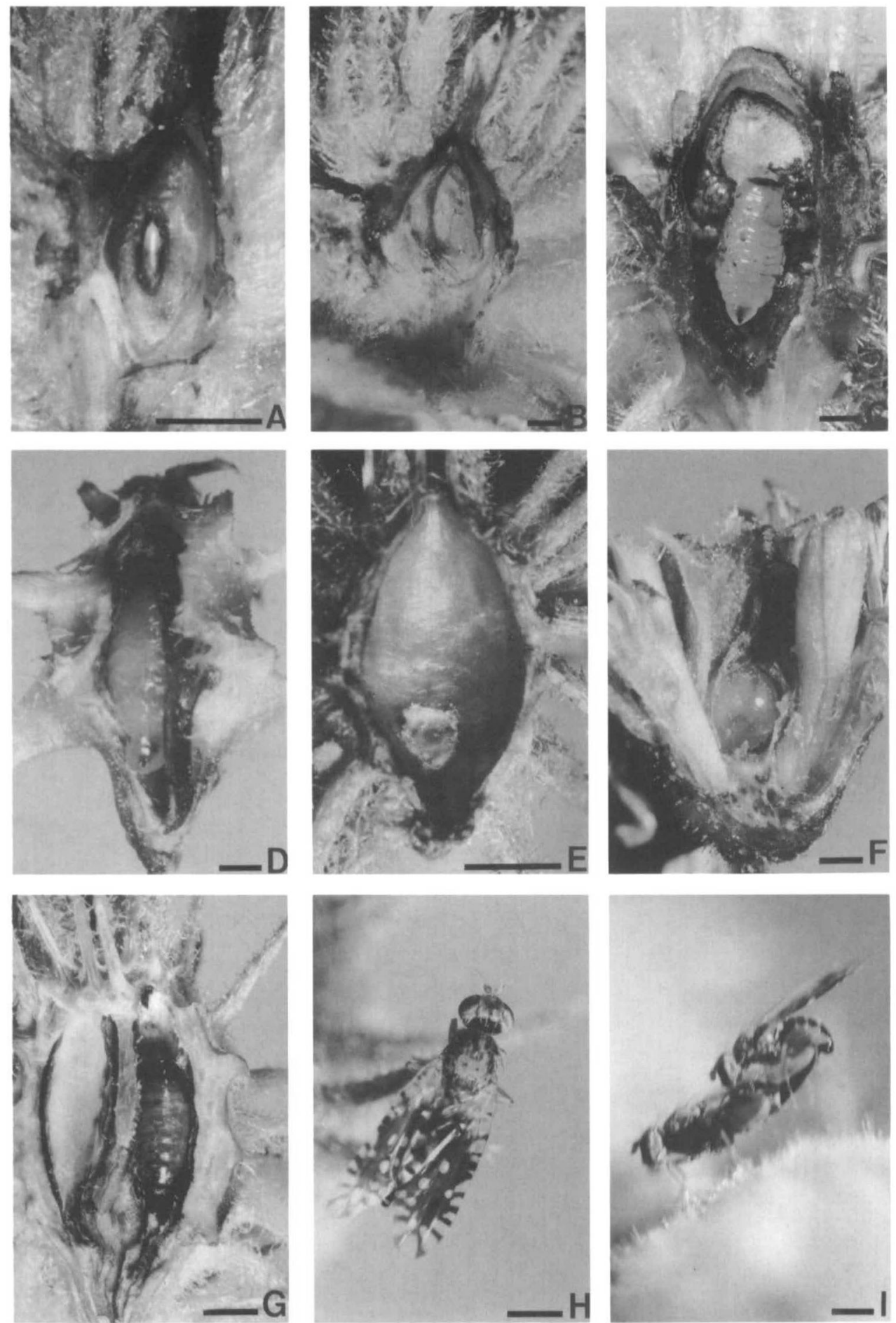

Fig. 7. Life stages of E. stigmatica from A. ilicifolia (A-C, E-G) and A. acanthicarpa (D): (A) Egg inserted into ovule of fruiting involucre, (B) second instar feeding in ovule, (C) third instar in feeding chamber in fruiting involucre, (D) third instar in feeding chamber, (E) view of excavated exit window from inside fruiting involucre, (F) third instar larva feeding centrally among florets of staminate involucre, (G) puparium in excavated chamber, (H) adult female, (I) pair in copula on fruiting involucre of A. ilicifolia taken in nature. 
Table 1. Distribution, abundance, and sex ratios of E. stigmatica on A. ilicifolia, Ed. Jaeger Preserve, spring 1992

\begin{tabular}{|c|c|c|c|c|c|c|c|c|c|c|}
\hline \multirow{2}{*}{$\begin{array}{c}\text { March } \\
\text { date }\end{array}$} & \multirow{2}{*}{$\begin{array}{l}\text { No. } \\
\text { stems }\end{array}$} & \multirow{2}{*}{$\begin{array}{c}\text { No. } \\
\text { adults } \\
\text { per stem }\end{array}$} & \multirow{2}{*}{ Range } & \multirow{2}{*}{$\begin{array}{l}\text { No. } \\
\text { males }\end{array}$} & \multirow{2}{*}{$\begin{array}{c}\text { No. } \\
\text { females }\end{array}$} & \multirow{2}{*}{ Total } & \multirow{2}{*}{$\begin{array}{c}\text { Sex } \\
\text { ratio }\end{array}$} & \multicolumn{2}{|c|}{ No. males } & \multirow{2}{*}{$\begin{array}{c}\text { Mated } \\
\text { pairs }\end{array}$} \\
\hline & & & & & & & & Courting & Resting & \\
\hline 4 & 40 & 2.1 & $1-4$ & 64 & 29 & 93 & $2.2: 1$ & - & - & - \\
\hline 11 & 14 & 1.9 & $1-4$ & 35 & 12 & 47 & $2.9: 1$ & 4 & 31 & 5 \\
\hline 18 & 30 & 1.5 & $1-3$ & 63 & 33 & 96 & $1.9: 1$ & 5 & 58 & 9 \\
\hline 24 & 30 & 1.5 & $1-4$ & 54 & 29 & 83 & $1.8: 1$ & 5 & 49 & 2 \\
\hline
\end{tabular}

had aborted and the larvae within had died. In one-third of the 157 fruiting involucres of $A$. ilicifolia examined in which one ovule was infested by a first instar, the other ovule within the involucre had died and shriveled and was rendered unsuitable for continued larval feeding and development. First instars molted after $\approx 1 \mathrm{wk}$ and continued to feed as second instars on the remaining ovule in involucres of $A$. ilicifolia (Fig. 7B). By the second molt, after $\approx 2 \mathrm{wk}$, much of the second ovule also was consumed. The uninfested seeds normally are white inside, but infested seeds become darkly stained, dried, and lined with frass compacted at both ends of the open ellipsoidal feeding chamber (Fig. 7C). Third instars continue to excavate the fruiting involucres, leaving intact only the dried, hard, and darkened fruit coats in both A. ilicifolia (Fig. 7C) and A. acanthicarpa (Fig. 7D). Most growth takes place during this third stadium, which lasts for $\approx 1 \mathrm{wk}$. The mature third instar is approximately half the length and about as wide as its feeding chamber. Before pupariation, the third instar scrapes away a small exit hole in the wall at the base of the involucre, leaving a translucent, circular, epidermal window (Fig. $7 \mathrm{E})$. Windows averaged $0.58 \pm 0.015 \mathrm{~mm}$ in diameter ( $n=25$; range, $0.43-0.73$ ) and were located $0.86 \pm 0.047 \mathrm{~mm}$ from the stalk of the involucre ( $n=25$; range, 0.51-1.47).

In staminate involucres, all larval stages feed within the pollen-bearing, staminate florets. No exit window is made and third instars orient with their heads directed outward in the hollowed-out feeding cavity before pupariation (Fig. 7F).

Puparium. Pupariation by E. stigmatica in a fruiting involucre is unusual in that the third instar does not face outward, but remains oriented with its head facing the base of the involucre, allowing the emerging adult direct access to the exit hole (Fig. 7G). In contrast, most, but not all (R.D.G. \& J.A.T., unpublished data), tephritids that we have studied position their exit windows toward the apex of a gall, or infested branch or stem (cf. Goeden 1988, Headrick \& Goeden 1990, Goeden \& Headrick 1991b, Goeden et al. 1993).

Adult. The spring, $\mathrm{F}_{1}$ generation of adults reared from A. ilicifolia lived an average of $76 \pm 3.5 \mathrm{~d}(n$ $=145$; range, 4-155) (Fig. $7 \mathrm{H})$. The fall, $F_{2}$ generation of adults from $A$. acanthicarpa were longer lived, averaging $168 \pm 17.7 \mathrm{~d}(n=46$; range, 24 312). Females always emerged reproductively im- mature, and required $4-6 \mathrm{wk}$ of feeding on protein hydrolyzate and honey to develop eggs in individual laboratory cagings. Females collected from rendezvous sites in early spring (see discussion below) were also reproductively immature, but collections of females from the same plant 1 wk later showed them to contain full-sized ova $(n=3)$.

Abundance. Field observations were made during $5 \mathrm{wk}$ at the Jaeger Reserve study site beginning on 25 February 1992 , when $\approx 20$ adults were recorded on the main study plant, the "rendezvous site" (Zwölfer 1974), but only 3 or fewer were found on other, nearby plants of comparable size. Table 1 records the numbers of adults present on this plant during the next $4 \mathrm{wk}$ beginning $4 \mathrm{March}$ 1992. Males consistently outnumbered females, but the total number of adults fluctuated considerably from week to week. The number of adults per stem were distributed relatively uniformally over the entire rendezvous plant during the observation period. Generally, from one to four individuals were observed on each stem, for averages of 1.5-2.1 adults per stem during the study period (Table 1). Adults of the next generation began emerging $2-3$ wk later. The daily pattern of abundance of $\mathrm{F}_{2}$ flies of both sexes also was monitored for the next $4 \mathrm{wk}$. Both sexes were abundant and active by 0930 hours, the greatest number of mated pairs was observed at $\approx 1200$ hours (maximum, 9 ) on each of the observation days, and the number of single males declined thereafter. The number of single females ovipositing remained high until $\approx 1500$ hours daily, after which adults were rarely observed.

Wing Displays. Under field conditions, E. stigmatica exhibited enantion, lofting, and rarely hamation and asynchronous supination as defined by Headrick \& Goeden (1991), Green et al. (1993), and Goeden et al. (1994b). The most common display by both sexes in field and laboratory observations was a unique form of enantion in which the wings were held flat over the dorsum and extended forward synchronously from the midline of the body through $\approx 90^{\circ}$ without supination. The extensions occurred in rapid bursts lasting $\approx 1 \mathrm{~s}$, with short pauses of 1-2 $s$ between each episode. Males exhibited this type of enantion most often and as a continuous part of their territorial display. Males also exhibited this enantion while in copula, especially when the females moved or otherwise were disturbed. 


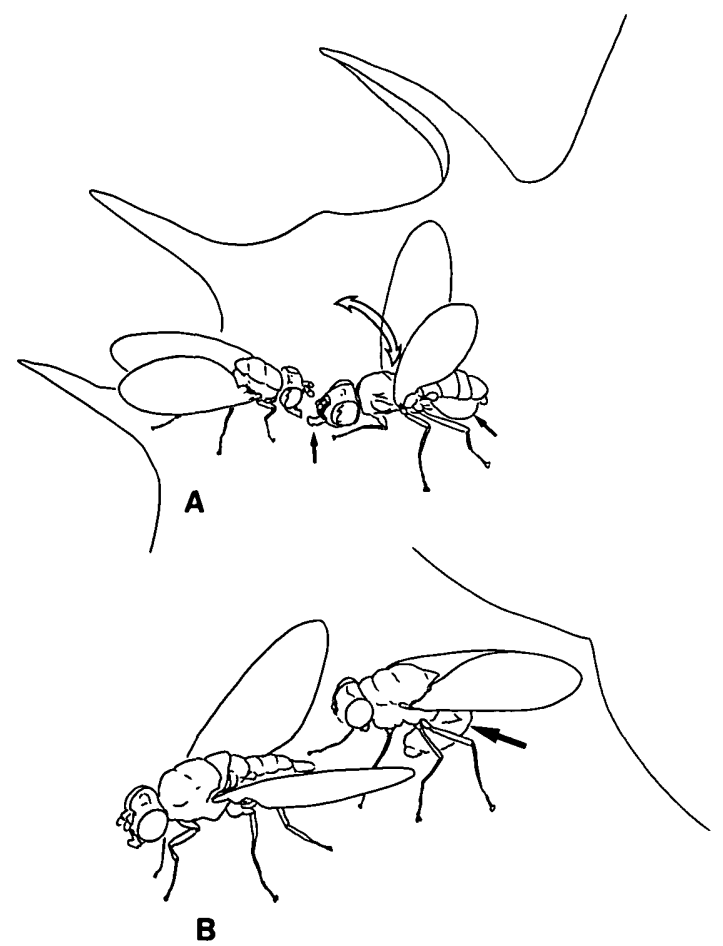

Fig. 8. (A) Male courtship display (drawn from field photo), male on right, arrows denote distended abdominal pleura, extended mouth parts, lofted wings, doubleheaded arrow denotes direction of lofting/dance display. (B) Male positioned behind female for aculeus exsertion (drawn from field photo), arrow denotes male abdomen curled underneath the body.

Males displayed an exaggerated form of lofting during courtship displays with females. The wings were lofted to $90^{\circ}$, perpendicular to the long axis of the body and parallel to each other (Fig. 8A). They were not vibrated while lofted but rather held in this position, while the male rocked his entire body vigorously from side to side (see Courtship section below). Wing lofting was similar to that of Paroxyna genalis (Goeden et al. 1994b), but in $E$. stigmatica the wings were held lofted at $90^{\circ}$ with respect to the substrate and parallel to each other. Only males displayed lofting in E. stigmatica. Males also displayed lofting in territorial bouts with other males, in which the wings were extended to only $45^{\circ}$ above the body, parallel to the midline of the body, with the wing blades parted $\approx 45^{\circ}$.

Courtship. In the field, males usually were observed on sunlit leaves while walking about the adaxial surfaces, observing, and orienting to face nearby flies. Little site fidelity was shown by males, as they only remained on a particular leaf for up to $15 \mathrm{~min}$, and often vacated a leaf after combat with other males whether they won or lost. However, all courtship and territorial displays by males took place on the adaxial surfaces of leaves.
In contrast, females continually moved about a plant while probing for ovipositional sites with the apices of their ovipositors in immature fruiting involucres, and much less frequently, in the staminate involucres. As they explored the plant in this manner, they encountered patrolling males perched on leaves. Males initially raised and lowered their fore legs once to any individual walking onto their leaf surface $(n=24)$. Other males answered in kind and combat usually ensued; however, females did not respond with any observable body movement and the males immediately initiated courtship ( $n=14$ ).

Males faced females, extended their mouthparts fully, distended their abdominal pleura, and crouched (Fig. 8A). If the females remained, males lofted their wings fully upright and began rocking their bodies from side to side rapidly for brief episodes lasting $\approx 2-3 \mathrm{~s}$ (Fig. 8A). Males did not keep their mouthparts extended during their courtship displays, but while a male rocked or danced, he extended his mouthparts and tried to place them against the female's mouthparts (Fig. 8A). The female responded by extending her mouthparts toward the male and briefly touching them or by extending them and moving toward the male as he backed away. No fluids were observed to be exchanged, as reported for several other species of tephritids whose premating trophallaxis required several minutes (Stolzfus \& Foote 1965, Headrick \& Goeden 1990, Goeden \& Headrick 1992). When a male displayed wing lofting/dancing during courtship, he stilted on his legs with his abdomen held higher than the rest of his body. During this dance, the male's tarsi did not move, only his body. This side-to-side dance was repeated often, and a male generally held his wings lofted until he moved behind a female.

Unreceptive females never permitted males to move into position behind them. The courting male moved sideways, side-stepping rapidly while facing the female, so as to position himself behind her. However, the unreceptive female held her wings flat and overlapped on her dorsum and turned in one spot, always facing the side-stepping male. Males often switched directions and sidestepped rapidly back and forth through $\approx 180^{\circ}$. If a female remained unreceptive, the male stopped side stepping, raised his front legs above his head, lowered his anterior end, extended his mouthparts, and either resumed side stepping in arcs around the female or began a lofting/dance display.

However, if the female was receptive, she allowed the male to get into position behind her. Once positioned behind the female, the male returned his wings to their resting position flat on his dorsum and deflated his abdominal pleura. $\mathrm{He}$ stood behind her, sometimes placed his fore tarsi on the tips of her wings, curled his abdomen forward beneath him, placed his epandrium at the apex of her ovipositor, and waited (Fig. 8B). If the female was unreceptive at this point, she did not 
exert her aculeus, and the male returned to face her again from the front. Once in front of her again, he raised both of his middle legs once, synchronously, high above his thorax, then dropped them to the substrate. After this middle leg abduction, he again began his lofting/dance display. After a few more episodes of the lofting/dance display, he again maneuvered behind the female, lowered his wings, deflated his pleura, and curled his abdomen beneath him so his epandrium again touched the apex of her oviscape.

Courtship displays with individual females continued for as long as a half hour or until an unreceptive female walked away. There were many distractions for courting males, such as other males moving in and initiating combat. Because of the high densities of flies on the study plant (Table 1), some males were observed to court two females simultaneously, all the while intermittently fighting with intruding males. The courting males were able to switch from their courtship displays to fighting displays (described below) and back again without pause.

Copulatory Induction Behavior. Males remained passive behind females, with their epandrium poised for the exsertion of the aculeus, while they sometimes touched the wing tips of the females with their fore tarsi. Thus, unlike other tephritid males studied to date, E. stigmatica males do not mount females before exsertion of the aculeus, and thus, do not rub their hind or middle legs on the oviscape of the female to stimulate exsertion of the aculeus.

Copulation. The male engaged the exserted aculeus with his surstyli as he mounted the female and wrapped his front legs around the middle of her abdomen. As he moved forward, her ovipositor was raised slightly. In this initial position, the male was stilted on his extended legs above the female, with his head over the middle of her abdomen, and his abdomen curled downward (Fig. 7I). The aculeus remained exserted, and pushed the male's abdomen backward. At this point the male began rubbing the oviscape with his hind legs, and intermittently displayed enantion, typical of copulatory induction behavior displays of other nonfrugivorous tephritid males such as Aciurina thoracica Curran (Headrick \& Goeden 1993) and Trupanea californica Malloch (Headrick \& Goeden 1991). The female sat quietly with her wings spread and mouthparts pumping during copulation. As insertion of the aedeagus proceeded, the aculeus was slowly retracted and the male moved slightly forward on the female. In his final position, the male's abdomen was bent downward only slightly, both his hind and middle legs 'were on the substrate, and his front legs grasped the abdomen of the female near her thorax. The final mating posture was achieved 2-3 min after initial exsertion of the aculeus. The female walked around while the male continued to use his middle and hind legs to groom or drum on the female's abdomen. The mated pair remained quiet, usually staying on or near the same leaf, and occasionally moved from sunlight into shade.

Encounters between males and mating pairs were frequent because of the high numbers of individuals on the plant (Table 1). Single males approached mating pairs and displayed toward the females. Some males attempted to mount mating pairs. These intruding males were met with aggressive lunges by the copulating females and wing displays by the copulating males. These interactions always ended with the intruding males departing $(n=5)$.

Timed copulations lasted an average of $1 \mathrm{~h}$ in the field ( $n=9$ observed from initiation to disengagement). Disengagement was quick. A male turned to one side, stepped down from the female's dorsum onto the substrate, and moved away from her while pulling his aedeagus from her aculeus. Once parted, they sat still apart from each other and groomed for a short time. Then, either one, and ultimately both flies moved off the leaf and onto other parts of the branch or nearby branches. In one instance, a female in copula walked away from the male while he remained stationary. She continued forward, pulling his abdomen forward underneath him. He stepped backward away from the female, and his aedeagus pulled free. This male then moved toward the female and began courtship displays, but soon stopped his displays and moved away from the female.

Oviposition. Females did not oviposit directly after disengagement from copulation, but rather usually sat grooming. Oviposition was observed most commonly in the afternoon, i.e., after $\approx 1300$ hours. Females walked upon and examined fruiting involucres of certain sizes, i.e., $>7 \mathrm{~mm}$ in diameter, or those with two stigmas exposed. They probed while facing away from the center of the involucre, where the tips of their oviscapes were directed. Oviposition followed probing and lasted $\approx 3-5 \mathrm{~min}$. Females remained on the fruit after oviposition and groomed and rested.

Feeding. Feeding by adults was readily observed in laboratory arenas and in field observations. Adults readily fed at water and protein sources provided in arenas and produced droplets as observed and described for other tephritid species (cf. Goeden \& Headrick 1992; Headrick \& Goeden 1991, 1993; Green et al. 1993). Adults in the field touched their mouthparts to leaves and branches, to fruiting and staminate involucres, and to the carcasses of dead arthropods.

Territoriality. A single leaf was patrolled by a male, and he displayed his front legs to any individual that moved onto this leaf. Intruding males answered in kind and ritual combat began ( $n=$ 10). During this combat, males faced each other with their abdominal pleura distended, wings partially lofted, and mouthparts extended. Battles began with the males drumming their raised front 
legs together. The males then dropped to the substrate, lowered their wings, and pressed their extended mouthparts together. They began to move from side to side asynchronously to each other, rubbing their extended mouthparts together at each pass. Some males moved off the leaf after this initial encounter, but other battles became more involved. If both males remained, they continued the battle by raising their front legs again and engaged in mouthpart rubbing. After this behavior, each male tried to turn sideways toward the other male and bat him with an extended, supinated wing. Each male also tried to grasp the other's wings with his front legs in a leg-lock, i.e., trapping the wing blade between the fore tibia and femur. They continued to wrestle and batter each other until one turned and moved away. The losers were usually chased by the victors until the former were on another branch or out of sight. Combat sessions lasted up to $5 \mathrm{~min}$ and ended with the victor returning or not returning to their leaf. Females were not attracted to males in combat. Male combat in other tephritid species has many similar components; e.g., appendage displays, mouth part extention and touching, stilting and wrestling, but these behaviors are rarely observed in natural field settings (Boyce 1934, Dodson 1985, Headrick \& Goeden 1990; unpublished data).

Batra (1979) described the courtship and mating behavior of $E$. bella and E. festiva from Ambrosia artemisifolia $\mathrm{L}$. and $A$. trifida $\mathrm{L}$., respectively. $E$. bella and $E$. festiva adults were most active in the late afternoon and both tended to remain on or near their host plants (Batra 1979). E. stigmatica adults were active from $\approx 0900$ to 1500 hours but females were generally more abundant and active after $\approx 1300$ hours.

Courtship behaviors for $E$. bella and $E$. festiva appear similar to those of $E$. stigmatica, except in terms of interpretation. Batra (1979) listed 10 courtship behavior "patterns" observed for both $E$. bella and $E$. festiva, "(1) visual orientation, (2) alternate wing waving with vibration, (3) both wings extended horizontally, (4) both wings extended with proboscis extended, (5) both wings extended with head butting, (6) tapping with front feet, (7) rapid flicks of both wings simultaneously, (8) territoriality (lekking), (9) male following female, abdomen curved, (10) male following female, wings flattened against abdomen." Interpreting the courtship sequence for $E$. bella and $E$. festiva as described by Batra (1979) is difficult because other behaviors beside courtship were involved simultaneously; e.g., aggression, male-male interactions, and female-female interactions. From the data she presented, we interpret that during courtship, males approached females with a wing display other than lofting; mouthpart contact was made; males of $E$. festiva followed females for courtship with their abdomens curved, their wings flat over their dorsa, and male courtship took place while females were ovipositing; whereas, $E$. bella males did not court ovipositing females. Also according to Batra (1979), males of both E. bella and E. festiva established territories, but of differing sizes. E. bella males had a territory of one or two leaves which they occupied for a few hours; however, $E$. festiva males had a territory of $1 \mathrm{~m}^{2}$, which individual males occupied for more than a few hours (Batra 1979). Copulation for $E$. festiva occurred late in the afternoon, and lasted for $\approx 1 \mathrm{~h}(n=2)$; copulation for $E$. bella occurred throughout the day and lasted 20-60 min $(n=15)$ (Batra 1979).

The behavioral similarities of both of these species, and especially E. festiva, to E. stigmatica is an example of the many shared behavioral attributes of congeners and helps to substantiate the closeness of these three species hypothesized by Norrbom (1993). Behaviors observed in all three species include wing enantion or "rapid flicks of both wings simultaneously," asynchronous supination or "alternate wing waving with vibration" (though less common in E. stigmatica), mouthpart contact, and territoriality. E. stigmatica and E. festiva also share two more features: males curling their abdomens underneath them and holding their wings flat over their dosa while sitting behind females. However, E. stigmatica did not court ovipositing females as did E. festiva, and copulations took place only on the upper surfaces of leaves patrolled or defended by males. Other behaviors reported here for $E$. stigmatica and not reported by Batra (1979) for E. bella and E. festiva include wing lofting, abdominal pleura distension, males raising their front legs as an initial greeting, male lofting/dance during courtship, a courting male's rapid side stepping to maneuver behind a female, a courting male raising his middle legs after initial rejection by an unreceptive female, and male ritual combat.

Seasonal History. E. bella and E. festiva are both monophagous and univoltine (Foote 1984, Foote et al. 1993); whereas E. stigmatica is bivoltine in southern California, producing a spring generation on $A$. ilicifolia and a fall generation on A. acanthicarpa (B. A. Foote reported rearing a spring generation of E. stigmatica from A. ambrosioides in southwest Arizona and noted that another host-plant species must be used by these adults because A. ambrosioides was no longer producing involucres, personal communication). $E$. bella adults are found from mid-June to late September in Ohio and Maryland, whereas E. festiva adults appear in July in Maryland and reach their peak abundance in mid-September (Batra 1979, Foote 1984). Both E. bella and E. festiva overwinter as diapausing larvae in fruiting involucres (Foote 1965, 1984; Batra 1979).

Adults of $E$. bella and $E$. festiva females emerged reproductively immature, but after a month mature, then oviposit for another month (Batra 1979). This compares with the similar prereproductive period of $4-6$ wk observed in the current study with caged $F_{1}$ adults of $E$. stigmatica 
reared from involucres of $\boldsymbol{A}$. ilicifolia collected at the Jaeger Reserve study site. These $F_{1}$ adults in nature apparently oversummer and reproduce in the fall in southern California on the widespread, annual ragweed, A. acanthicarpa. E. stigmatica then overwinters as $F_{2}$ adults that rendezvous on A. ilicifolia in the Colorado Desert in the spring to reproduce and complete the cycle. Reproduction by $E$. bella and $E$. festiva was concurrent with the flowering of their sole hosts (Batra 1979, Foote 1984), as with bivoltine E. stigmatica on its two hosts in southern California.

Natural Enemies. The principal natural enemies of immature E. stigmatica in fruiting and staminate involucres of $A$. acanthicarpa and $A$. ilicifolia were the solitary, primary, larval-pupal, endoparasitic, chalcidoid Hymenoptera, Eurytoma sp. (Eurytomidae) and Pteromalus sp. (Pteromalidae). Both wasp genera are commonly associated with other nonfrugivorous, florivorous Tephritidae in southern California, but additional taxonomic study is needed to determine how many and what species of these parasitoids are involved, for which our voucher specimens may someday find use. Also reared in limited numbers from $A$. ilicifolia involucres infested by E. stigmatica were the following chalcidoid Hymenoptera, that also presumably are solitary, primary parasitoids: Heteroschema sp. (Pteromalidae) and ?Glyphomerus sp. (Torymidae).

Biological Control. The role of E. aequalis as a seed predator of cocklebur, Xanthium strumarium L., has long been known (Marlatt 1891); accordingly, it was one of the first insects exported to Australia in 1932 from its native United States for the biological control of this annual, noxious weed (Julien 1992). Though established at low levels, it afforded no cocklebur control. Subsequent transfers of $E$. aequalis from Australia to Fiji in 1951 failed to establish this fly (Julien 1992).

The reproductive behaviors of $E$. bella and $E$. festiva were studied by Batra (1979) to help to assess their potential for use as biological control agents of adventive North American ragweeds in Eurasia. E. bella had been exported to the then U.S.S.R. from the United States and Canada in 1969 and 1977, but was not established on Ambrosia artemisiifolia (Kovalev 1980, Julien 1992). E. bella was introduced again in 1990 from the United States and released in the North Caucasus, but its establishment remains unconfirmed (Julien 1992).

Euaresta stigmatica from A. acanthicarpa in southern California, like E. festiva and Ambrosia trifida in eastern North America, remains under consideration as a biological control agent for ragweeds in Eurasia (Harris \& Piper 1970, Goeden \& Teerink 1993). The former species remains untested in the field as a biological control agent for A. trifida, to which E. stigmatica would have to transfer if exported and released in Eurasia. A. acanthicarpa is the native ragweed most closely al- lied taxonomically to A. artemisiifolia and A. trifida (Payne 1963), but unlike them has not been accidentally exported from North America as an agricultural weed and a growing, worrisome source of aeroallergenic pollen in Eurasia. Therefore, if it can be successfully induced to attack these two ragweeds, E. stigmatica obtained from A. acanthicarpa, in comparison with $E$. bella and E. festiva attacking their natural host plants, may provide a good test of the so-called "new-host theory" of Hokkanen \& Pimentel (1984). It was in this context that the current study of E. stigmatica was undertaken, as our contribution to a new cooperative research and natural enemy exchange program between Agriculture Canada and the Academy of Agricultural Sciences of the People's Republic of China involving, among other projects, the biological control of ragweeds (Goeden \& Teerink 1993; R.D.G.; unpublished data).

\section{Acknowledgments}

We thank A. C. Sanders of the Herbarium, Department of Botany and Plant Sciences, University of California, Riverside, for identifying the plants mentioned in this study. The parasitoids were identified by G. Gordh when he was with the Systematic Entomology Laboratory, USDA-ARS, Washington, DC. We also thank F. L. Blanc, B. A. Foote, and P. Harris for their helpful comments on early drafts of the manuscript.

\section{References Cited}

Batra, S.W.T. 1979. Reproductive behavior of Euaresta bella and E. festiva (Diptera: Tephritidae), potential agents for the biological control of adventive North American ragweeds (Ambrosia spp.) in Eurasia. N.Y. Entomol. Soc. 87: 118-125.

Boyce, A. 1934. Bionomics of the walnut husk fly, Rhagoletis completa. Hilgardia. 8: 363-579.

Dodson, G. 1985. Lek mating system and large male aggressive advantage in a gall-forming tephritid fly (Diptera: Tephritidae). Ethology 72: 99-1.08.

Foote, B. A. 1965. Biology and immature stages of eastern ragweed flies (Tephritidae). Proc. North Cent. Branch Entomol. Soc. Am. 20: 105-106.

1984. Host plant records for North American ragweed flies (Diptera: Tephritidae). Entomol. News 95: 5154.

Foote, R. H., F. L. Blane \& A. L. Norrbom. 1993. Handbook of the fruit flies (Diptera: Tephritidae) of America North of Mexico. Cornell University Press, Ithaca, NY.

Goeden, R. D. 1988. Gall formation by the capituluminfesting fruit fly, Tephritis stigmatica (Diptera: Tephritidae). Proc. Entomol. Soc. Wash. 90: 37-43.

Goeden, R. D. \& D. H. Headrick. 1991a. Notes on the biology, hosts, and immature stages of Tomoplagia cressoni Aczel in southem California (Diptera: Tephritidae). Proc. Entomol. Soc. Wash. 93: 549-558.

1991b. Life history and descriptions of immature stages of Tephritis baccharis (Coquillett) on Baccharis salicifolia (Ruiz \& Pavon) Persoon in southern California (Diptera: Tephritidae). Pan-Pac. Entomol. 67: $86-98$ 
1992. Life history and descriptions of immature stages of Neaspilota viridescens Quisenberry (Diptera: Tephritidae) on native Asteraceae in southern California. Proc. Entomol. Soc. Wash. 94: 59-77.

Goeden, R. D. \& D. W. Ricker. 1974a. The phytophagous insect fauna of the ragweed, Ambrosia acanthicarpa, in southern California. Environ. Entomol. 3: 827-34.

1974.b. The phytophagous insect fauna of the ragweed, Ambrosia chamissonis, in southern California. Environ. Entomol. 3: 835-39.

1975. The phytophagous insect fauna of the ragweed, Ambrosia confertiflora, in southern California. Environ. Entomol. 4: 301-306.

1976a. The phytophagous insect fauna of the ragweed, Ambrosia dumosa, in southern California. Environ. Entomol. 5: 45-50.

1976b. The phytophagous insect fauna of the ragweed Ambrosia chenopodiffolia, A. eriocentra, and A. ilicifolia, in southern California. Environ. Entomol. 5: 923-930.

1976c. The phytophagous insect fauna of the ragweed, Ambrosia psilostachya, in southern California. Environ. Entomol. 5: 1169-1177.

1986. Phytophagous insect fauna of the desert shrub, Hymenoclea salsola, in southern California. Ann. Entomol. Soc. Am. 79: 39-47.

Goeden, R. D. \& J. A. Teerink. 1993. Phytophagous insect faunas of Dicoria canescens and Iva axillaris, native relatives of ragweeds, Ambrosia spp., in southern California, with analyses of insect associates of Ambrosiinae. Ann. Entomol. Soc. Am. 86: 37-50.

Goeden, R. D., D. H. Headrick \& J. A. Teerink. 1993. Life history and descriptions of immature stages of Tephritis arizonaensis Quisenberry (Diptera: Tephritidae) on Baccharis sarothroides Gray in southem California. Proc. Entomol. Soc. Wash. 95: 210 222.

1994a. Life history and description of immature stages of Procecidochares flavipes Aldrich (Diptera: Tephritidae) on Brickellia spp. in southern California. Proc. Entomol. Soc. Wash. 96: 288-300.

1994.b. Life history and description of immature stages of Paroxyna genalis (Thomson) (Diptera: Tephritidae) on native Asteraceae in southern California. Proc. Entomol. Soc. Wash. 96: 612-629.

Green, J. F., D. H. Headrick \& R. D. Goeden. 1993. Life history and description of immature stages of Procecidochares stonei Blanc \& Foote on Viguiera spp. in southern California (Diptera: Tephritidae). Pan-Pac. Entomol. 69: 18-32.

Harris, P. \& G. L. Piper. 1970. Ragweed (Ambrosia spp.: Compositae): its North American insects and possibilities for its biological control. Commonw. Inst. Biol. Control. Tech. Bull. 13: 117-140.
Headrick, D. H. \& R. D. Goeden. 1990. Life history of Paracantha gentilis (Diptera: Tephritidae). Ann. Entomol. Soc. Am. 83: 776-785.

1991. Life history of Trupanea californica Malloch (Diptera: Tephritidae) on Gnaphalium spp. in southern California. Proc. Entomol. Soc. Wash. 93: 559570.

1993. Life history and description of immature stages of Acuirina thoracica (Diptera: Tephritidae) on Baccharis sarothroides in southern California. Ann. Entomol. Soc. Am. 86: 68-79.

Hilgendorf, J. H. \& R. D. Goeden. 1983. Phytophagous insect fauna of spiny cocklebur, Xanthium strumarium, in southern California. Environ. Entomol 12: 404-411.

Hokkanen, H. \& D. Pimentel. 1984. New approach for selecting biological control agents. Can. Entomol. 116: 1109-1121.

Julien, M. H. 1992. Biological control of weeds. A world catalogue of agents and their target weeds, 3rd ed. CAB, Wallingford, UK.

Kovalev, O. V. 1980. Biological control of weeds: accomplishments, problems, and prospects. Zasch. Rast. (Mosc.) 5: 18-21 (in Russian with English abstract).

Marlatt, C. L. 1891. The Xanthium Trypeta. Proc. Entomol. Soc. Wash. 2: 40-43.

Munz, P. A. 1968. Supplement to a California flora. University of California Press, Berkeley.

1974. A flora of southern California. University of California Press, Berkeley.

Norrbom, A. L. 1993. New species and phylogenetic analysis of Euaresta Loew (Diptera: Tephritidae), with a key to the species from the Americas south of Mexico. Proc. Entomol. Soc. Wash. 95: 1.95-209.

Novak, J. A. \& B. A. Foote. 1968. Biology and description of immature stages of fruit flies: Paroxyna albiceps (Diptera: Tephritidae). J. Kans. Entomol. Soc. 41: 108-119.

Payne, W. W. 1963. The morphology of the inflorescence of ragweeds (Ambrosia-Franseria: Compositae). Am. J. Bot. 50: 872-880.

Phillips, V. T. 1946. The biology and identification of trypetid larvae (Diptera: Tephritidae). Mem. Am. Entomol. Soc. 12: 1-161.

Stoltzfus, W. B. \& B. A. Foote. 1965. The use of froth masses in courtship of Eutreta (Diptera: Tephritidae). Proc. Entomol. Soc. Wash. 67: 262-264.

Zwölfer, H. 1974. Das Treffpunkt-prinzip als Kommunikationsstrategie und Isolationsmechanismus bei Bohrfliegen (Diptera: Trypetidae). Entomol. Ger. 1: 11-20.

Received for publication 28 April 1994; accepted 2 August 1994. 